\title{
Effect of Fertilizer Application on Groudwater Quality at an Oil
}

\section{Palm Plantation}

\author{
M. Edwin S Lubis ${ }^{1 *}$, Zaharah A Rahman ${ }^{1}$, Christopher Teh. B. S ${ }^{1}$, M. M. Hanafi ${ }^{2}$, I. YaniHarahap ${ }^{1}$, \\ Taufiq C. Hidayat $^{1} \&$ Y. Pangaribuan ${ }^{1}$ \\ ${ }^{1}$ Indonesian Oil Palm Research Institute (IOPRI), Medan, Indonesia \\ ${ }^{2}$ Universiti Putra Malaysia (UPM), Kuala Lumpur, Malaysia \\ * M. Edwin S Lubis, E-mail: edwinlubis1970@gmail.com
}

Received: February 6, 2017

Accepted: February 20, 2016 Online Published: February 24, 2017

doi:10.22158/se.v2n1p67

URL: http://dx.dx.doi.org/10.22158/se.v2n1p67

\begin{abstract}
Oil palm plantations need fertilizers for optimum growth and production. However, excessive use of fertilizers can lead to pollution of groundwater. For this reason, a study was carried out to investigate groundwater quality of an oil palm ecosystem, which involved the measurement of 9-point monitor wells and run-off. This research was conducted in Kabun-Aliantan (N: 0002.925' E: 100049.977'). Tandun, Riau-Indonesia. The location points of the monitored wells in this study comprised a young oil palm area (P1), an adult oil palm area near Lau river (P2), a housing complex at oil palm plantation (P3), an adult oil palm area at Marihat, Block A (P4), a housing 1 at the sub-district town (P5), a housing 2 at the sub-district town (P6), a cocoa area (P7), a village housing (P8), at the side of Lau river (PR), and a run-off in a micro catchment (N: 00027.936' E: 100049, 977'). The parameters analyzed in the water samples were $p H$, nitrate- $N(N O 3-N)$, nitrite- $N(N O 2-N)$, ammonium- $N(N H 4-N)$, phosphate $(P)$, potassium (K), calcium (Ca) and magnesium ( $M g$ ).

In general, $p H, N O 3-N, N O 2-N, N H 4-N, P, K, C a$ and $M g$ increased after fertilizer application and decreased with time. All levels of parameters were lower than the WHO standard for drinking water. This study showed that the fertilizers on the oil palm plantation did not pollute the groundwater quality. However, groundwater pollution was found to be caused by residential wastes, such as the use of detergents and other human activities.
\end{abstract}

Keywords

oil palm plantation, fertilizer applications, groundwater quality

\section{Introduction}

To obtain the optimal production of oil palm, optimum fertilizer is required to replenish nutrients in the soil. Large quantities of nitrogen and potassium are crucial to support oil palm production although 
ground water pollution caused by agricultural activities is a serious problem in many regions of the world. A study by Michinori (2002) showed that high rates of $\mathrm{N}$ fertilizer used in continuous production of corn have resulted in excessive nitrate- $\mathrm{N}$ leaching in groundwater which frequently exceeded the maximum contamination level of $10 \mathrm{mg} \mathrm{L}-1$.

The adverse health effects of high nitrate levels in drinking water are well documented (Michinori, 2002). The most common health problems are methemo-globinemia, gastric cancer, and non-Hodgkin's lymphoma. While the usual level of ammonium (NH4) ion does not pose a direct risk to human health, a high NH4 concentration may suggest the presence of more agricultural contaminants such as pesticides. Furthermore, in aerobic condition, NH4 may be transformed into nitrate (NO3-) via nitrification. Since groundwater is an indispensable water resource for human consumption especially in developing countries, and the fact that contaminants in the groundwater will eventually be discharged into rivers or streams which is also a source of drinking water, most authors refer to the drinking water standard guidelines as a baseline to assess the contamination level. WHO has set the maximum admissible limits in drinking water for NO3-N as 10 and NH4+-N as $0.5 \mathrm{mg} \mathrm{L}-1$. Although there is little evidence that $\mathrm{K}$ in drinking water is detrimental to human health, an increase in $\mathrm{K}$ concentration in groundwater may lead to a breach of the drinking water limit of $\mathrm{K}$ of $12 \mathrm{mg} \mathrm{L}-1$. In addition, leaching losses of nutrient may move the nutrients further downward and eventually cause groundwater pollution (Petronella et al., 2009).

Although various studies on groundwater contamination due to fertilization in different crops have been carried out, there is still very little information available on the effects of fertilization on groundwater quality in oil palm plantation.

\section{Materials and Methods}

This experiment was carried out from 2010 to 2011 at Kabun-Aliantan (N: 00027.925' E: 100049.219') in Tandun, Riau, Indonesia, at an existing oil palm plantation established on Typic Hapludult or Typic Paleudult, a type of soil with a clayey texture located on a flat landscape area between 30 and 70 meters above the sea level (PPKS, 1999). Groundwater sampling was done before fertilizer application on 5 October 2010, and at day 3, 7, 14, 30, 60, and 90 after the application of fertilizer. The areas of research are presented in Table 1.

Pipe well observation was conducted at all experimental locations by placing pipe wells made of PVC in 9 observed locations. Each location was equipped with three pipe wells, which inter-point position has an equilateral triangle design with each side measuring $9 \mathrm{~m}$ in length and $7.62 \mathrm{~cm}$ in diameter (Figure 1) (Harahap, 2009). 


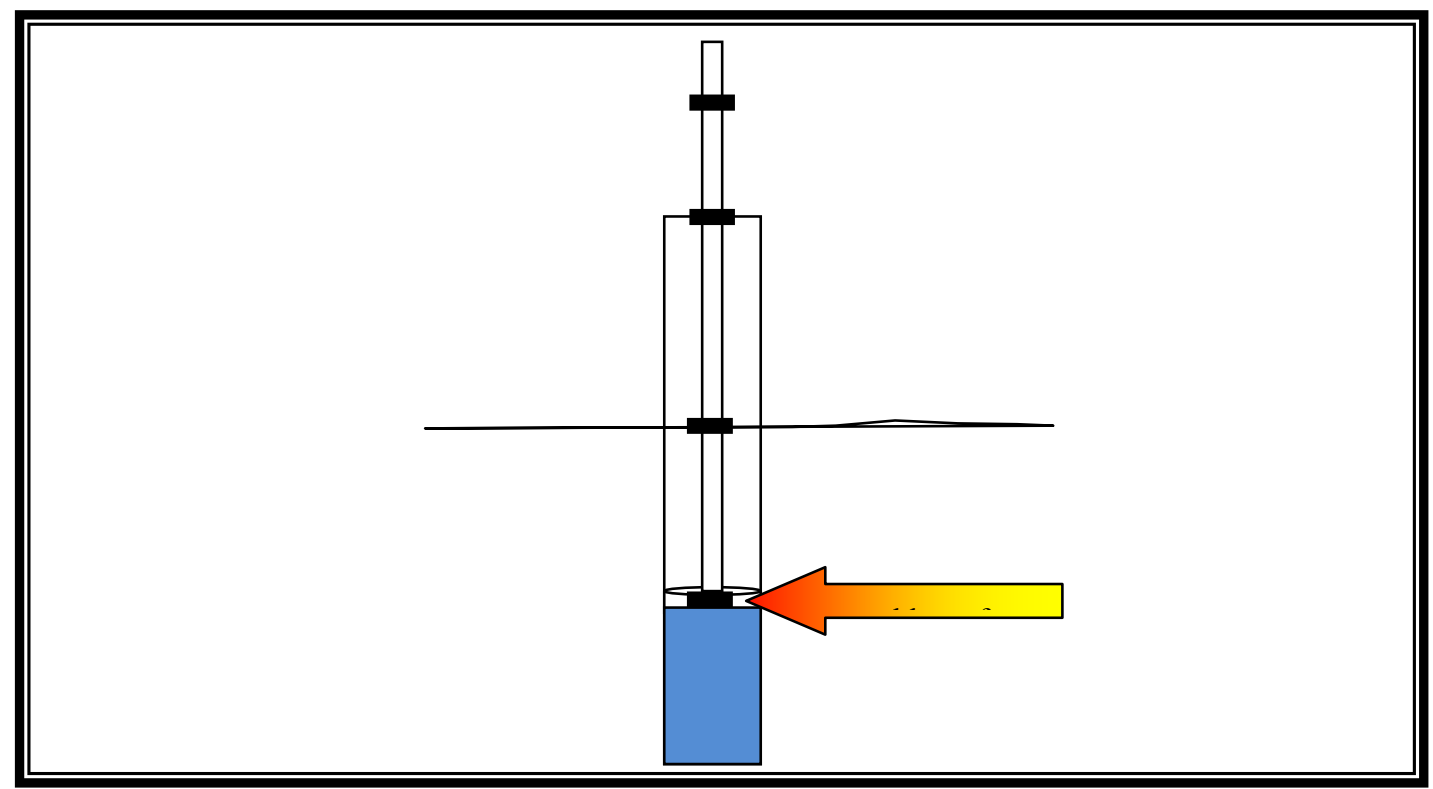

Figure 1. Pipe Well

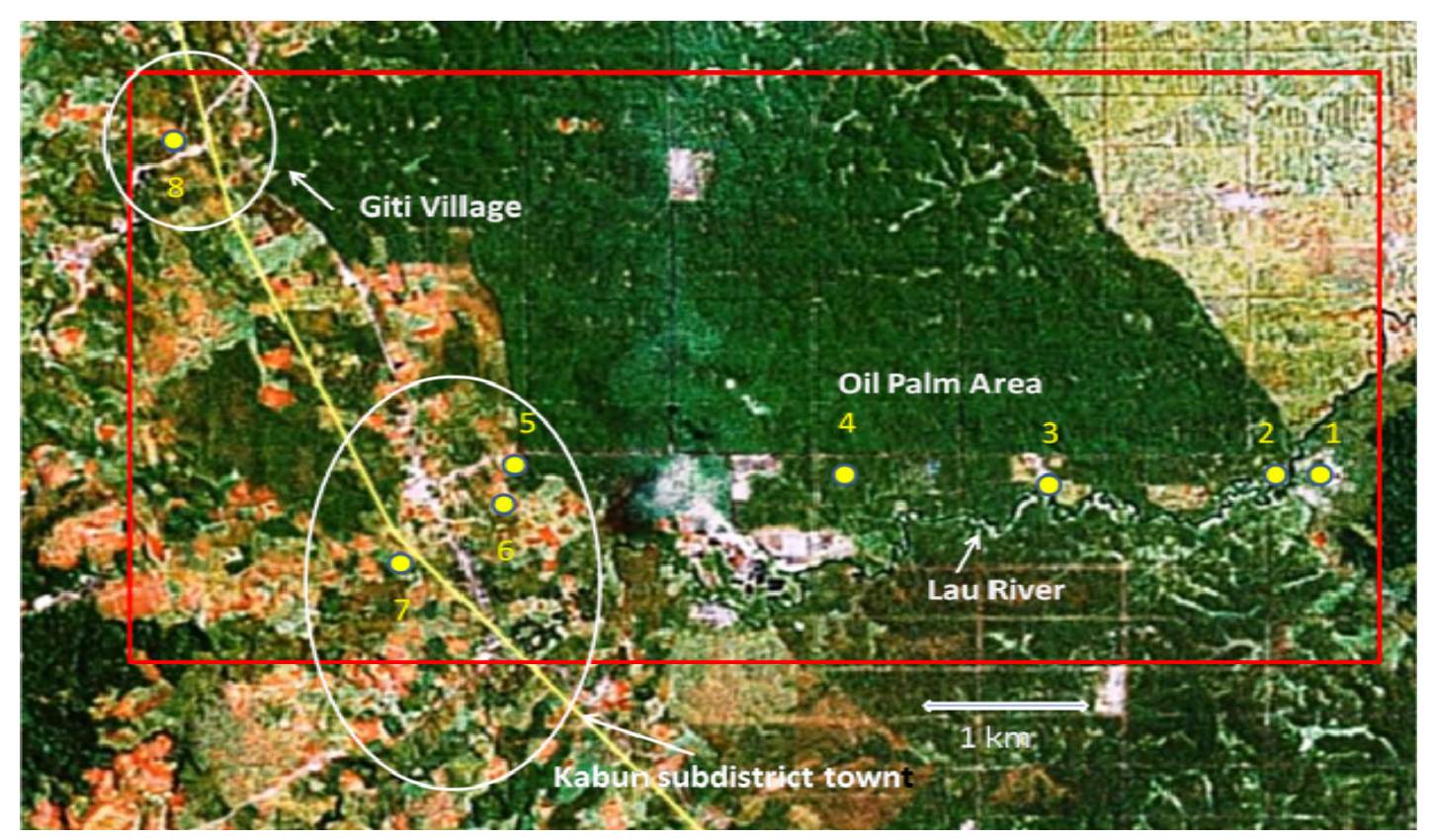

Figure 2. The Point Spread Monitoring Wells at Oil Palm Plantations and the Surrounding Area in the Watershed Aliantan-Kabun, Riau

Table 1. Distribution of the Well Points in the Kabun-Aliantan Watershed

\begin{tabular}{clccc}
\hline No & \multicolumn{1}{c}{ Locations } & Geographical positions & Above sea level (m) & Codes \\
\hline 1 & Young oil palm area (planted in 2004) & N: $00^{0} 27.948^{\prime}$ E: $100^{0} 50.262^{\prime}$ & 41 \\
2 & Adult oil palm area near Lau river (planted in 1992) & N: $00^{0} 27.925^{\prime}$ E: $100^{0} 50.202^{\prime}$ & 38 & P1 \\
\hline
\end{tabular}




\begin{tabular}{|c|c|c|c|c|}
\hline 3 & Housing complex at oil palm plantation & $\mathrm{N}: 00^{0} 27.925^{\prime} \mathrm{E}: 100^{\circ} 49.219^{\prime}$ & 44 & P3 \\
\hline 4 & Adult oil palm area atMarihat, BlockA (planted in 1989) & $\mathrm{N}: 00^{0} 27.936$ ' E: $100^{\circ} 49.977^{\prime}$ & 48 & $\mathrm{P} 4$ \\
\hline 5 & Housing 1 at the sub-district town & $\mathrm{N}: 00^{0} 27.700^{\prime} \mathrm{E}: 100^{\circ} 47.060^{\prime}$ & 53 & P5 \\
\hline 6 & Housing 2 at the sub-district town & $\mathrm{N}: 00^{0} 27.927^{\prime} \mathrm{E}: 100^{\circ} 47.208^{\prime}$ & 56 & P6 \\
\hline 7 & Cocoaarea & N: $00^{0} 27.566^{\prime}$ E: $100^{\circ} 46.9611^{\prime}$ & 59 & $\mathrm{P} 7$ \\
\hline 8 & Village housing & $\mathrm{N}: 00^{0} 29.121^{\prime} \mathrm{E}: 100^{\circ} 45.797$ ' & 63 & P8 \\
\hline 9 & At the side of Lau river & $\mathrm{N}: 00^{0} 27.925^{\prime} \mathrm{E}: 100^{0} 50.202^{\prime}$ & 38 & PR \\
\hline 10 & Run-Off & $\mathrm{N}: 00^{0} 27.9366^{\prime} \mathrm{E}: 100^{\circ} 49.977^{\prime}$ & 48 & Run-Off \\
\hline
\end{tabular}

The oil palms were fertilized two times with the same dose of NPK fertilizer, with nutrient compositions of 15:9:20:2 at 3.75 kg palm-1 in each application. The nutrient contents of the fertilizer were $15 \% \mathrm{~N}$ (Nitrogen), 9\% P2O5, 20\% K2O and 2\% MgO, with the addition of 3.8\% S, $0.02 \% \mathrm{Mn}$ and $0.02 \% \mathrm{Zn}$. Dolomite $(20 \% \mathrm{MgO}, 30 \% \mathrm{Ca})$ with particle size distribution of less than 1 mesh was given at $2.50 \mathrm{~kg}$ palm-1 in each application. The water micro catchment areas were made using an area of $50 \times 50$ meters (2500 meters square) to collect the run-off samples. Run-off observations were conducted in the oil palm growing area labelled as P4. The run-off and groundwater samplings were taken before fertilization application, and 3, 7, 14, 30, 60 and 90 days after the application. Then, the water samples were analyzed to determine the levels of chemical properties. Water sampling in this study was done using a small tube with a diameter of $5 \mathrm{~mm}$, a $50 \mathrm{ml}$ syringe, and a small hose mounted on the tip of the syringe that carried out the sample suction of water in each monitored well.

The analyzed parameters in the water samples were $\mathrm{pH}$, Nitrate $(\mathrm{NO} 3-\mathrm{N})$, Nitrite $(\mathrm{NO} 2-\mathrm{N})$, Ammonium (NH4-N), Phosphate (P), Potassium (K), Calcium (Ca) and Magnesium (Mg). A pH meter was used for measuring the $\mathrm{pH}$ levels of the water samples. Meanwhile, the content of nitrate (NO3-N) ions was identified using the brushing method with sulphate (APHA, 1992), whereas nitrite (NO2-N) was identified utilizing the diazotise method. On the other hand, absorption was measured using a spectrophotometer (APHA, 1992). Ammonium (NH4-N) analysis was carried out by employing the principle of ammonium in an alkaline solution, which will react with Nessler (K2HgIa). Potassium (K), Calcium (Ca) and Magnesium ( $\mathrm{Mg}$ ) were examined using atomic absorption spectrophotometer according to APHA standard method (APHA, 1992).

Completely randomized design (CRD) was used with 3 replicates and all data were analysed using the analysis of variance (ANOVA) and the LSD test. 


\section{Results and Discussion}

\section{1 pH Analysis}

The results for the $\mathrm{pH}$ of the water sample in this study are presented in Table 2 below:

Table 2. Analysis of the Water Sample pH

\begin{tabular}{|c|c|c|c|c|c|c|c|c|c|c|c|c|c|c|c|}
\hline Parameter & Sample & \multicolumn{2}{|c|}{ Day 0} & \multicolumn{2}{|c|}{ Day 3} & \multicolumn{2}{|c|}{ Day 7} & \multicolumn{2}{|c|}{ Day 14} & \multicolumn{2}{|c|}{ Day 30} & \multicolumn{2}{|c|}{ Day 60} & \multicolumn{2}{|c|}{ Day 90} \\
\hline \multirow{10}{*}{ pH } & $\mathrm{P} 1$ & 5.02 & $\mathrm{C}$ & 5.03 & $\mathrm{D}$ & 5.05 & D & 5.07 & $\mathrm{C}$ & 5.01 & D & 5.10 & $\mathrm{D}$ & 4.73 & E \\
\hline & $\mathrm{P} 2$ & 5.18 & $\mathrm{C}$ & 5.20 & $\mathrm{CD}$ & 5.21 & D & 5.24 & $\mathrm{C}$ & 5.13 & D & 5.20 & $\mathrm{CD}$ & 4.81 & E \\
\hline & P3 & 5.08 & $\mathrm{C}$ & 5.23 & $\mathrm{CD}$ & 5.32 & D & 5.84 & B & 6.31 & B & 5.80 & B & 5.78 & $\mathrm{BC}$ \\
\hline & P4 & 6.03 & B & 6.28 & $\mathrm{AB}$ & 6.34 & $\mathrm{AB}$ & 6.44 & A & 6.73 & A & 6.10 & B & 6.21 & $\mathrm{AB}$ \\
\hline & P5 & 5.93 & B & 6.01 & B & 5.43 & $\mathrm{CD}$ & 6.78 & A & 5.92 & $\mathrm{C}$ & 6.30 & $\mathrm{AB}$ & 6.01 & B \\
\hline & P6 & 6.28 & A & 6.34 & $\mathrm{AB}$ & 6.43 & A & 6.47 & A & 6.51 & A & 6.80 & A & 6.27 & $\mathrm{AB}$ \\
\hline & P7 & 6.43 & A & 6.78 & A & 5.28 & D & 6.48 & A & 6.20 & B & $6.40 \mathrm{H}$ & & 6.78 & A \\
\hline & P8 & 5.09 & $\mathrm{C}$ & 5.24 & D & 5.81 & B & 5.87 & B & 5.11 & $\mathrm{D}$ & 5.20 & $\mathrm{C}$ & 5.16 & $\mathrm{D}$ \\
\hline & PR & 5.07 & $\mathrm{C}$ & 5.16 & $\mathrm{D}$ & 5.62 & $\mathrm{C}$ & 5.74 & B & 5.21 & D & 4.90 & $\mathrm{D}$ & 4.76 & $\mathrm{E}$ \\
\hline & Run-Off & 5.29 & $\mathrm{C}$ & 5.53 & $\mathrm{C}$ & 6.50 & A & 6.54 & A & 5.72 & $\mathrm{C}$ & 6.50 & $\mathrm{AB}$ & 5.35 & $\mathrm{C}$ \\
\hline
\end{tabular}

*Note. The values followed by the same letters in the same column are not significantly different at $\mathrm{P} \geq$ 5\% (LSD), P1: young oil palm area, P2: adult oil palm area near Lau river (planted in 1992), P3: housing complex at oil palm plantation, P4: adult oil palm area at Marihat, Block A (planted in 1989), P5: housing 1 at the sub-district town, P6: housing 2 at the sub-district town, P7: cocoa area, P8: village housing, PR: at the side of Lau River.

Table 2 shows that the $\mathrm{pH}$ levels vary widely in all pipe wells at the time of sampling. The variation of $\mathrm{pH}$ ranged from 4.73 to 6.80 . The highest $\mathrm{pH}$ value in the water samples was obtained at $\mathrm{P} 6$ treatment of the water sampling on Day 60 after the application of fertilizer, which was equal to 6.80 . On the other hand, the lowest $\mathrm{pH}$ value was identified at $\mathrm{P} 1$ treatment after 90 days after the application of fertilizer, which was 4.73 .

The highest $\mathrm{pH}$ measurement collected during the study was 6.80 which met the $\mathrm{pH}$ requirement level of drinking water. WHO (1993) set $\mathrm{pH} 8.5$ as the quality requirement for drinking water. High $\mathrm{pH}$ in the water samples was caused by fertilizer dolomite [CaMg (CO3)2] in this study. Buckman and Brady (1982) stated that the provision of dolomite could increase soil $\mathrm{pH}$. High and low $\mathrm{pH}$ levels indicate the presence of hydrogen ion in water. Notably, identifying the $\mathrm{pH}$ levels is very important because they indicate occurrences of the chemical and biochemical reactions at certain $\mathrm{pH}$ levels; for instance, nitrification process will stop if the $\mathrm{pH}$ value is low. In the human body, water $\mathrm{pH}$ greater than 9.2 will cause some chemical compounds to become toxic (Effendi, 2003). Data collected in the study showed 
that none of the $\mathrm{pH}$ levels indicated above exceeded the level in the threshold requirements of drinking water quality. All the tested pipe wells are suitable for drinking purpose.

Based on the LSD test after 90 days of fertilization, the result at P4 was not significantly different while the results at P3, P5, P6, and P7 were significantly different from P1, P2, P8, PR, and the runoff. According to Alamendah (2010), human activities are one of the causes of water pollution which was created due to residential or household wastes (garbage). Residential waste water contains household wastes in the forms of organic and inorganic wastes such as detergents. The $\mathrm{pH}$ at oil palm plantation (P4) increases a little from 6.03 before the application of fertilizer. It increases to $6.21,90$ days after the application of fertilizer. The result shows that $\mathrm{pH}$ increase is particularly due to the presence of cations such as Calcium, Magnesium, and Sodium (Ogunwale \& Azzez, 2000).

\subsection{Nitrate-N (NO3) Analysis}

Nitrate-N (NO3-N) of the water sample analysis in this study is presented in Table 3 below:

Table 3. Analysis of Nitrate-N (NO3-N) in the Water Samples

\begin{tabular}{|c|c|c|c|c|c|c|c|c|c|c|c|c|c|c|c|}
\hline \multirow[t]{2}{*}{ Parameter } & \multirow{2}{*}{$\begin{array}{l}\text { Sample } \\
\text { P1 }\end{array}$} & \multicolumn{2}{|c|}{ Day 0} & \multicolumn{2}{|c|}{ Day 3} & \multicolumn{2}{|c|}{ Day 7} & \multicolumn{2}{|c|}{ Day 14} & \multicolumn{2}{|c|}{ Day 30} & \multicolumn{2}{|c|}{ Day 60} & \multicolumn{2}{|c|}{ Day 90} \\
\hline & & 0.17 & A & 0.23 & & 0.00 & E & 0.17 & $\mathrm{C}$ & 0.00 & $\mathrm{D}$ & 0.00 & $\mathrm{D}$ & 0.00 & B \\
\hline \multirow{9}{*}{$\begin{array}{l}\text { Nitrate-N } \\
\left(\mathrm{NO}_{3}{ }^{-} \mathrm{N}\right) \\
\mathrm{mg} \mathrm{L}^{-1}\end{array}$} & $\mathrm{P} 2$ & 0.16 & A & 0.20 & B & 0.06 & $\mathrm{DE}$ & 0.00 & $\mathrm{D}$ & 0.00 & $\mathrm{D}$ & 0.01 & $\mathrm{D}$ & 0.00 & B \\
\hline & P3 & 0.00 & $\mathrm{C}$ & 0.11 & $\mathrm{D}$ & 0.85 & A & 0.06 & $\mathrm{D}$ & 0.00 & $\mathrm{D}$ & 0.00 & $\mathrm{D}$ & 0.00 & B \\
\hline & P4 & 0.00 & $\mathrm{C}$ & 0.06 & E & 0.06 & DE & 0.06 & $\mathrm{D}$ & 0.00 & D & 0.00 & D & 0.00 & B \\
\hline & P5 & 0.06 & B & 0.11 & $\mathrm{D}$ & 0.17 & $\mathrm{C}$ & 0.24 & B & 0.97 & A & 0.51 & A & 0.00 & B \\
\hline & P6 & 0.00 & $\mathrm{C}$ & 0.01 & $\mathrm{~F}$ & 0.17 & $\mathrm{C}$ & 0.00 & $\mathrm{D}$ & 0.00 & D & 0.00 & $\mathrm{D}$ & 0.00 & B \\
\hline & P7 & 0.00 & $\mathrm{C}$ & 0.07 & $\mathrm{DE}$ & 0.05 & $\mathrm{DE}$ & 0.00 & $\mathrm{D}$ & 0.12 & $\mathrm{C}$ & 0.00 & D & 0.00 & B \\
\hline & P8 & 0.20 & A & 0.26 & A & 0.34 & B & 0.34 & A & 0.68 & B & 0.29 & B & 0.28 & A \\
\hline & PR & 0.0 & $\mathrm{BC}$ & 0.17 & $\mathrm{C}$ & 0.11 & $\mathrm{D}$ & 0.1 & $\mathrm{CD}$ & 0.00 & D & 0.11 & $\mathrm{C}$ & 0.00 & B \\
\hline & Run-Off & 0.00 & $\mathrm{C}$ & 0.28 & A & 0.34 & B & 0.40 & A & 0.00 & D & 0.00 & D & 0.00 & B \\
\hline
\end{tabular}

*Note. The values followed by the same letters in the same column are not significantly different at $\mathrm{P} \geq$ 5\% (LSD), P1: young oil palm area, P2: adult oil palm area near Lau river (planted in 1992), P3: housing complex at oil palm plantation, P4: adult oil palm area at Marihat, Block A (planted in 1989), P5: housing 1 at the sub-district town, P6: housing 2 at the sub-district town, P7: cocoa area, P8: village housing, PR: at the side of Lau River.

Table 3 shows that the highest concentration of Nitrate-N (NO3-N) in the water samples $(0.97 \mathrm{mg}$ L-1) was obtained at P5 on day 30. However, the lowest value of Nitrate-N (NO3-N) concentration in some of the sampling points was not detected. As mentioned earlier, WHO (1993) has set $10 \mathrm{mg}$ L-1 as the maximum limit of Nitrate-N (NO3-N) in groundwater acceptable for drinking. Hence, it can be concluded that the Nitrate-N (NO3-N) concentration in the water samples area is still acceptable. This 
is because excessive amount of Nitrate-N (NO3-N) content in soil-water can cause bloody diarrhea and mental disorders (Widodo, 2008).

Based on the LSD test on day 90 after the application of fertilizer, it was shown that P4 was only significantly different with P8 but was not significantly different with other locations. Thus, it can be concluded that fertilizers do not have any effects in increasing Nitrate-N (NO3-N) in groundwater quality.

When nitrogen fertilization is applied, it is transformed to Ammonium (NH4+) by soil enzymes. As ammonium (NH4+) tends to be strongly absorbed by soil particles, its movement through the soil is inhibited. Ammonium is an energy-rich substance, and certain soil bacteria can utilize this energy by decomposing the ammonium to Nitrate-N (NO3-N). Unlike ammonium, Nitrate-N (NO3-N) is not absorbed by soil particles and therefore, moves readily with water in the soil. Nitrate-N (NO3-N) that is not taken up by plant roots or soil micro-organisms can be transported to ground and surface water by a variety of mechanisms (Divya, 2012).

Nitrate-N (NO3-N) concentration was not detected at P3, P4 (oil palm plantation) and runoff; however, it increased to the highest concentration after day 7 of the application of fertilizer at (P3) and day 14 after the application of fertilizer at P4 and runoff. After 60 days, the concentrations of Nitrate-N $(\mathrm{NO} 3-\mathrm{N})$ in groundwater and runoff were not detected. Nitrate-N $(\mathrm{NO}-\mathrm{N})$ is soluble and mobile as Nitrate-N (NO3-N) leaching is a naturally occurring process. It is not harmful when it is within the root zone, but once it gets into the groundwater, it pollutes the environment (Jeyaruba, 2009).

3.3 Nitrite (NO2-N) Analysis

The Nitrite-N (NO2-N) analysis of water samples obtained in this study is presented in Table 4 below:

Table 4. Analysis of Nitrite-N (NO2-N) in the Water Samples

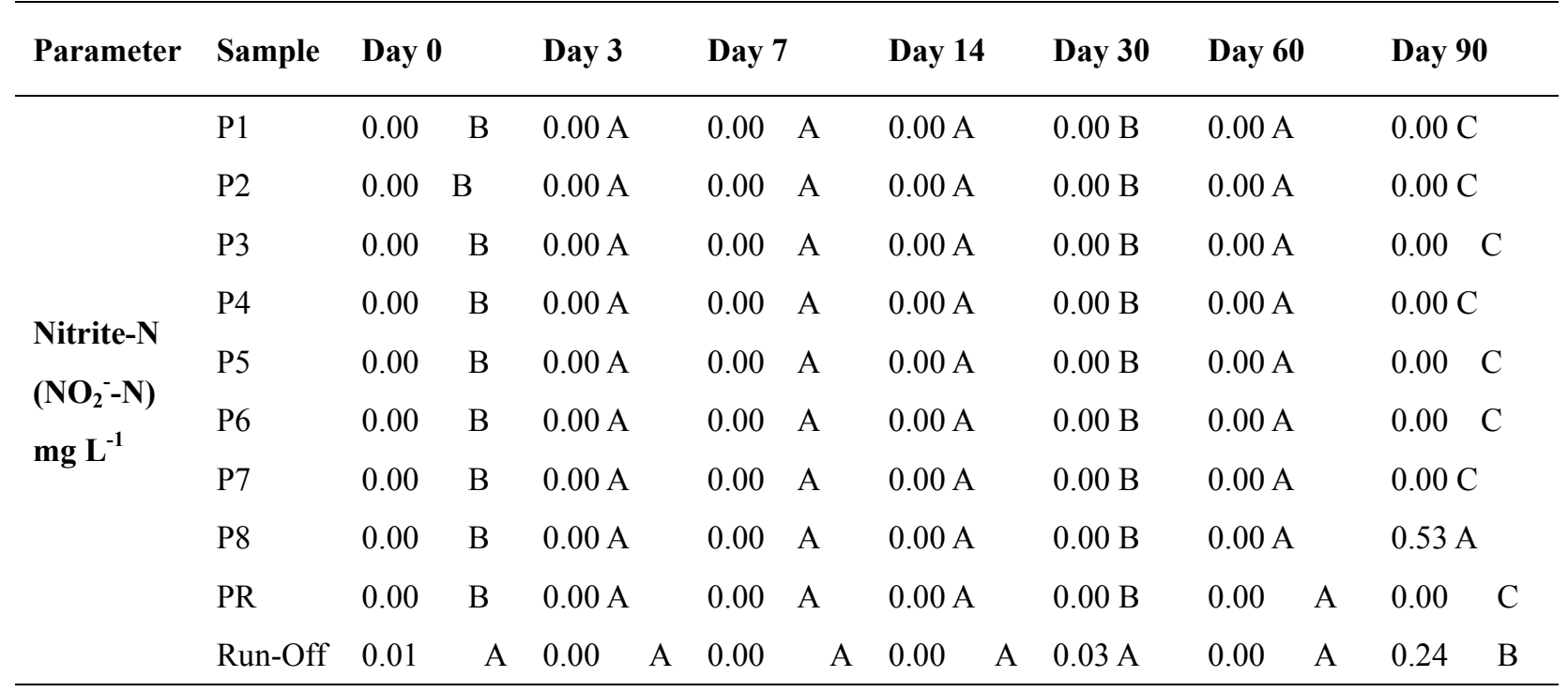

*Note. The values followed by the same letters in the same column are not significantly different at $\mathrm{P} \geq$ 5\% (LSD), P1: young oil palm area, P2: adult oil palm area near Lau river (planted in 1992), P3: 
housing complex at oil palm plantation, P4: adult oil palm area at Marihat, Block A (planted in 1989), P5: housing 1 at the sub-district town, P6: housing 2 at the sub-district town, P7: cocoa area, P8: village housing, PR: at the side of Lau River.

Table 4 shows that the highest Nitrite-N (NO2-N) concentration in the water samples of this study $(0.53$ mg L-1) was obtained at P8 on day 90. The lowest value of Nitrite-N (NO2-N) concentrations in some of the sampling points were not detected. WHO (1993) has set $1 \mathrm{mg} \mathrm{L}-1$ as the maximum limit for Nitrite-N (NO2-N) in groundwater that is accepted for drinking. Therefore, it can be concluded that the concentrations of Nitrite-N (NO2-N) in the water samples in the study area are still acceptable. According to Utama (2008), Nitrite-N (NO2-N) can easily mix with water. Furthermore, Winata (2000) stated that the presence of Nitrite-N (NO2-N) in a certain amount can be harmful to health because it can react with haemoglobin in the blood, which then prevents the blood from transporting oxygen to body cells.

Based on the LSD test carried on Day 90 after fertilization, it was revealed that P4 was not significantly different from P1, P2, P3, P5, P6, P7, and PR; however, P4 was significantly different from P8 and the runoff. Thus, we can conclude that fertilization has no effect in increasing Nitrite-N (NO2-N) in groundwater quality. Nitrite- $\mathrm{N}(\mathrm{NO} 2-\mathrm{N})$ is an intermediate product in the conversion of Ammonium to Nitrite-N (NO2-N) (Nitrification). It is usually present in low quantity, and is toxic to plants.

3.4 Ammonium (NH4-N) Analysis

Ammonium-N (NH4-N) analysis of the water samples in this study is presented in Table 5 below:

Table 5. Analysis of Ammonium-N (NH4-N) in the Water Samples

\begin{tabular}{|c|c|c|c|c|c|c|c|c|c|c|c|c|c|c|c|}
\hline \multirow[t]{2}{*}{ Parameter } & \multirow{2}{*}{$\begin{array}{l}\text { Sample } \\
\text { P1 }\end{array}$} & \multicolumn{2}{|c|}{ Day 0} & \multicolumn{2}{|c|}{ Day 3} & \multicolumn{2}{|l|}{ Day 7} & \multicolumn{2}{|c|}{ Day 14} & \multicolumn{2}{|c|}{ Day 30} & \multicolumn{2}{|c|}{ Day 60} & \multicolumn{2}{|c|}{ Day 90} \\
\hline & & 0.17 & $\mathrm{D}$ & 2.52 & $\mathrm{C}$ & 0.01 & $\mathrm{D}$ & 0.01 & $\mathrm{C}$ & 0.00 & $\mathrm{D}$ & 0.00 & $\mathrm{D}$ & 1.57 & $\mathrm{C}$ \\
\hline \multirow{9}{*}{$\begin{array}{l}\text { Ammonium } \\
\left(\mathrm{NH}_{4}-\mathrm{N}\right) \\
\mathrm{mg} \mathrm{L}^{-1}\end{array}$} & $\mathrm{P} 2$ & 0.01 & $\mathrm{D}$ & 0.26 & E & 0.02 & $\mathrm{D}$ & 0.01 & $\mathrm{C}$ & 1.00 & $\mathrm{C}$ & 0.01 & $\mathrm{D}$ & 2.48 & B \\
\hline & P3 & 0.09 & D & 0.43 & E & 0.01 & D & 0.01 & $\mathrm{C}$ & 0.09 & $\mathrm{D}$ & 0.09 & $\mathrm{D}$ & 0.01 & $\mathrm{E}$ \\
\hline & $\mathrm{P} 4$ & 0.17 & $\mathrm{D}$ & 0.17 & E & 0.09 & $\mathrm{D}$ & 0.08 & $\mathrm{C}$ & 0.22 & $\mathrm{CD}$ & 0.24 & $\mathrm{D}$ & 0.13 & E \\
\hline & P5 & 1.48 & A & 6.52 & $\mathrm{~A}$ & 25.22 & B & 15.65 & B & 9.57 & $\mathrm{~A}$ & 14.78 & A & 7.83 & A \\
\hline & P6 & 0.78 & B & 0.57 & $\mathrm{DE}$ & 0.17 & $\mathrm{D}$ & 0.25 & $\mathrm{C}$ & 0.61 & $\mathrm{CD}$ & 0.35 & $\mathrm{CD}$ & 0.17 & E \\
\hline & P7 & 0.68 & $\mathrm{BC}$ & 1.22 & $\mathrm{D}$ & 0.10 & $\mathrm{D}$ & 0.26 & $\mathrm{C}$ & 0.45 & $\mathrm{CD}$ & 0.11 & $\mathrm{D}$ & 0.43 & $\mathrm{DE}$ \\
\hline & P8 & 0.09 & $\mathrm{D}$ & 4.35 & $\mathrm{~B}$ & 0.78 & $\mathrm{C}$ & 14.70 & B & 9.74 & A & 12.17 & $\mathrm{~B}$ & 0.77 & $\mathrm{D}$ \\
\hline & PR & 0.09 & $\mathrm{D}$ & 0.61 & $\mathrm{DE}$ & 0.01 & $\mathrm{D}$ & 0.01 & $\mathrm{C}$ & 0.08 & $\mathrm{D}$ & 14.76 & A & 0.17 & $\mathrm{E}$ \\
\hline & Run-Off & 0.52 & $\mathrm{C}$ & 0.26 & E & 30.44 & A & 28.70 & A & 6.96 & B & 0.77 & $\mathrm{C}$ & 0.09 & E \\
\hline
\end{tabular}

*Note. The values followed by the same letters in the same column are not significantly different at $\mathrm{P} \geq$ 5\% (LSD), P1: young oil palm area, P2: adult oil palm area near Lau river (planted in 1992), P3: housing complex at oil palm plantation, P4: adult oil palm area at Marihat, Block A (planted in 1989), 
P5: housing 1 at the sub-district town, P6: housing 2 at the sub-district town, P7: cocoa area, P8: village housing, PR: at the side of Lau River.

Table 5 shows that the highest ammonium-N (NH4-N) concentration (30.44 mg L-1) was obtained from the runoff water samples 7 days after fertilization. However, the value of ammonium-N (NH4-N) concentration was not detected on day 30 and day 60 after the application of fertilizer at P1. The data obtained showed that the highest concentration of ammonia-N (NH4-N) was $30.44 \mathrm{mg} \mathrm{L-1}$, indicating that it had surpassed the maximum level of $0.5 \mathrm{mg} \mathrm{L}-1$ set by WHO (1993). Thus, the ammonia-N (NH4-N) level in the research area was not eligible. However, subsequent data showed that the high ammonia-N (NH4-N) level gradually decreased and eventually re-stabilized. Hoek (1994) stated that high level of ammonia-N (NH4-N) in water was due to contamination of the drinking water sources by organic materials. In water, Ammonia-N (NH4-N) is broken down by bacteria into nitrite-N by nitrisomonas. In drinking water supplies, ammonia-N (NH4-N) is known to cause irritation and corrosion, increase the growth of microorganisms, and disrupt the process of disinfection with chlorine. Based on the LSD test, the results were not significantly different at P3, P4, P6, P7, PR and runoff; however, the results were significantly different at P1, P2, P5 and P8 (the housing village). The value of ammonium-N (NH4-N) concentration at the housing village (P8) was the highest at 30.44. This value is higher than the standard set by WHO. Alamendah (2010) stated that organic and inorganic wastes such as residential wastes and detergents have the highest potential of being pollutants of water. According to Sastrawijaya (2000), the presence of ammonia is an indicator of entry for waste settlements. Alaerts and Santika (1987) also stated that ammonia in surface water originated from urine, faeces, and microbiological oxidation of organic matters from residential wastes. This opinion is supported by Kumar (1987) who mentioned that domestic waste water contains ammonia from the decay of crop and animal protein, as well as dirt. Kristianto (2002) also stated that dead plants and animals, described as protein, are broken down by spoilage organisms into ammonia and ammonium-N (NH4-N) compounds.

\subsection{Phosphate (P) Aanalysis}

The phosphate $(\mathrm{P})$ analysis of the water samples in this study is presented in Table 6 below:

Table 6. Analysis of Phosphate (P) in the Water Samples

\begin{tabular}{lllllllllllllllllll}
\hline Parameter & Sample & Day 0 & Day 3 & & Day 7 & & \multicolumn{1}{c}{ Day 14 } & \multicolumn{3}{c}{ Day 30 } & \multicolumn{2}{c}{ Day 60 } & \multicolumn{2}{c}{ Day 90 } \\
\hline & P1 & 0.00 & B & 0.02 & E & 0.00 & D & 0.00 & D & 0.02 & B & 0.00 & E & 0.27 & A \\
& P2 & 0.00 & B & 0.02 & E & 0.00 & D & 0.00 & D & 0.00 & C & 0.02 & D & 0.23 & B \\
Phosphate & P3 & 0.00 & B & 0.02 & E & 0.02 & D & 0.00 & D & 0.02 & B & 0.02 & D & 0.08 & E \\
mg L $^{-1}$ & P4 & 0.02 & B & 0.05 & D & 0.02 & D & 0.01 & D & 0.02 & B & 0.06 & C & 0.05 & EF \\
& P5 & 0.15 & A & 0.17 & A & 0.09 & B & 0.01 & D & 0.04 & A & 0.08 & B & 0.12 & D \\
& P6 & 0.00 & B & 0.00 & E & 0.00 & D & 0.02 & CD & 0.00 & C & 0.00 & E & 0.13 & D \\
\hline
\end{tabular}




\begin{tabular}{lcccccccccccccc}
\hline P7 & 0.00 & $\mathrm{~B}$ & 0.04 & $\mathrm{D}$ & 0.02 & $\mathrm{D}$ & 0.21 & $\mathrm{~B}$ & 0.00 & $\mathrm{C}$ & 0.02 & $\mathrm{D}$ & 0.19 & $\mathrm{C}$ \\
P8 & 0.00 & $\mathrm{~B}$ & 0.08 & $\mathrm{C}$ & 0.06 & $\mathrm{C}$ & 0.02 & $\mathrm{CD}$ & 0.02 & $\mathrm{~B}$ & 0.02 & $\mathrm{D}$ & 0.13 & $\mathrm{D}$ \\
PR & 0.00 & $\mathrm{~B}$ & 0.13 & $\mathrm{~B}$ & 0.37 & $\mathrm{~A}$ & 0.04 & $\mathrm{C}$ & 0.00 & $\mathrm{C}$ & 0.12 & $\mathrm{~A}$ & 0.02 & \\
Run-Off & 0.00 & $\mathrm{~B}$ & 0.04 & $\mathrm{D}$ & 0.35 & $\mathrm{~A}$ & 0.38 & $\mathrm{~A}$ & 0.02 & $\mathrm{~B}$ & 0.06 & $\mathrm{C}$ & 0.04 & $\mathrm{EF}$ \\
\hline
\end{tabular}

*Note. The values followed by the same letters in the same column are not significantly different at $\mathrm{P} \geq$ 5\% (LSD), P1: young oil palm area, P2: adult oil palm area near Lau river (planted in 1992), P3: housing complex at oil palm plantation, P4: adult oil palm area at Marihat, Block A (planted in 1989), P5: housing 1 at the sub-district town, P6: housing 2 at the sub-district town, P7: cocoa area, P8: village housing, PR: at the side of Lau River.

The highest phosphate $(\mathrm{P})$ concentration in the water samples was obtained from the runoff 14 days after fertilization, which was $0.38 \mathrm{mg} \mathrm{L}-1$. However, the lowest phosphate concentration of some of the samples was not detected. WHO (1993) has set that the threshold value of phosphate (P) for drinking water is $0.1 \mathrm{mg} \mathrm{L}-1$. The increase in the concentration of phosphate $(\mathrm{P})$ in the runoff on day 14 was due to the fertilizer treatment in the area surrounding the block; however, the concentration of phosphate $(\mathrm{P})$ re-stabilized after 90 days of water sampling, as shown in Table 6 .

Based on the LSD test on day 90 after fertilization, it was shown that P4 was not significantly different with P3, PR, and runoff, but it was significantly different with other locations. This study also shows that the pipe wells in the housing and district city P2, P5, P6, and P8, the concentrations of phosphate (P) were found to be higher than the level set by WHO for drinking water ( $>0.1 \mathrm{mg} \mathrm{L}-1)$. According to Hammer and Viessman (2005), the main forms of phosphorus in liquid domestic wastes are organic phosphorus, ortho-phosphate (H2PO4-, HPO42-, PO43-), and polyposphates. The two types of Polyphosphate (P) are sodium hexametaphosphate (Na3(PO3)6) and sodium pyrophosphate (Na4P2O7). Most phosphorus that enters the surface water comes from human wastes and runoff. Winata (2000) stated that polyphosphate can enter the wastewater stream through the population and industries that use materials containing phosphate detergents such as washing industry, metal industry, etc.

\subsection{Potassium (K) Analysis}

Potassium (K) analysis of water samples in this study is presented in Table 7 below:

Table 7. Analysis of Potassium (K) in the Water Samples

\begin{tabular}{llllllllllllllllll}
\hline Parameter & Sample & Day 0 & & Day 3 & & Day 7 & & Day 14 & Day 30 & & Day 60 & \multicolumn{2}{c}{ Day 90 } & \\
& & P1 & 0.02 & D & 0.48 & B & 0.77 & CD & 0.61 & D & 0.49 & F & 0.06 & E & 0.61 & F \\
\multirow{2}{*}{ Potassium } & P2 & 0.04 & D & 0.18 & C & 0.68 & D & 0.56 & D & 0.47 & F & 0.05 & E & 0.61 & F \\
mg L $^{-1}$ & P3 & 0.05 & D & 0.15 & CD & 1.21 & CD & 1.53 & C & 1.59 & E & 0.22 & DE & 1.57 & E \\
& P4 & 0.47 & B & 0.46 & B & 2.35 & B & 2.43 & B & 2.75 & D & 2.89 & C & 3.03 & C \\
\hline
\end{tabular}




\begin{tabular}{lllllllllllllll}
\hline P5 & 0.53 & B & 1.07 & A & 4.91 & A & 4.60 & A & 6.21 & B & 6.23 & B & 6.14 & B \\
P6 & 0.05 & D & 0.09 & D & 1.40 & C & 1.21 & CD & 1.17 & E & 1.15 & D & 1.40 & E \\
P7 & 0.00 & D & 0.04 & DE & 2.86 & B & 0.80 & CD & 0.66 & F & 0.64 & DE & 1.03 & EF \\
P8 & 1.02 & A & 1.19 & A & 4.82 & A & 5.33 & A & 7.39 & A & 8.47 & A & 10.64 & A \\
PR & 0.00 & D & 0.00 & E & 0.80 & CD & 0.49 & D & 0.46 & F & 0.49 & DE & 0.55 & F \\
Run-Off & 0.20 & C & 0.06 & DE & 5.08 & A & 5.22 & A & 4.08 & C & 8.75 & A & 2.36 & D \\
\hline
\end{tabular}

Note. The values followed by the same letters in the same column are not significantly different at $\mathrm{P} \geq$ 5\% (LSD), P1: young oil palm area, P2: adult oil palm area near Lau river (planted in 1992), P3: housing complex at oil palm plantation, P4: adult oil palm area at Marihat, Block A (planted in 1989), P5: housing 1 at the sub-district town, P6: housing 2 at the sub-district town, P7: cocoa area, P8: village housing, PR: at the side of Lau River.

The highest concentration of potassium $(\mathrm{K})$ in the water samples $(10.64 \mathrm{mg} \mathrm{L}-1)$ was obtained at P8 water sampling, 90 days after fertilization, while the concentration of potassium $(\mathrm{K})$ was not detected in the water samples at PR treatment 3 days after fertilization. The concentrations of potassium $(\mathrm{K})$ in the plantation area still met the drinking water standards according to the provision of WHO (1993) as the standard potassium (K) in drinking water is $12 \mathrm{mg} \mathrm{L}-1$. Petronella et al. (2009) argued that although there is little evidence that $\mathrm{K}$ in drinking water is harmful to human health, increasing concentrations of $\mathrm{K}$ in the soil can result in a violation of drinking water, in which the limit is $\mathrm{K} 12 \mathrm{mg} \mathrm{L}-1$.

Based on the LSD test on Day 90 after fertilization, it was found that P4 was significantly different for all the treatments. Following the research results, it can be seen that the increasing concentrations of potassium $(\mathrm{K})$ fertilizer did not influence the treatment at $\mathrm{P} 4$.

A higher $\mathrm{K}$ concentration in the sample was also found. This could be due to the displacement of $\mathrm{K}$ from the soil colloidal surfaces to soil solution by $\mathrm{NH} 4$ from the nitrogen fertilizer. Moreover, vegetative uptake of NH4 will increase the production of $\mathrm{H}$ in the soil (Galloway, 1995) which then displaced K (Van et al., 2002).

3.7 Calcium (Ca) Analysis

Calcium $(\mathrm{Ca})$ analysis of the water samples in this study is presented in Table 8 below:

Table 8. Analysis of Calcium (Ca) in the Water Samples

\begin{tabular}{llllllllll}
\hline Paramete & Sample & Day 0 & Day 3 & Day 7 & Day 14 & Day 30 & Day 60 & \multicolumn{2}{c}{ Day 90 } \\
\hline & P1 & 3.72 & 3.72 & 1.44 & 1.57 & 1.76 & 1.49 & 7.82 & DE \\
& P2 & 3.21 & 4.12 & 1.42 & 1.49 & 1.49 & 1.42 & 1.54 & F \\
Calcium & P3 & 0.48 & 3.05 & 1.55 & 1.35 & 2.54 & 1.28 & 1.57 & F \\
mg L $^{-1}$ & P4 & 8.96 & 26.92 & 23.17 & 24.48 & 62.51 & 62.39 & 30.70 & B \\
& P5 & 6.57 & 21.18 & 15.44 & 10.93 & 16.75 & 17.61 & 14.81 & C \\
& P6 & 11.78 & 16.41 & 30.87 & 29.66 & 74.29 & 78.21 & 36.98 & A \\
\hline
\end{tabular}




\begin{tabular}{lllllllll}
\hline P7 & 12.24 & 32.83 & 23.45 & 28.44 & 78.34 & 81.16 & 36.21 & A \\
P8 & 2.18 & 3.83 & 5.18 & 4.89 & 5.64 & 6.62 & 3.57 & \\
PR & 1.09 & 0.71 & 1.13 & 0.96 & 1.07 & 0.75 & 0.78 & \\
Run-Of & 3.06 & 9.53 & 23.80 & 24.31 & 21.00 & 41.19 & $11.60 \mathrm{CD}$ \\
\hline
\end{tabular}

*Note. The values followed by the same letters in the same column are not significantly different at $\mathrm{P} \geq$ 5\% (LSD), P1: young oil palm area, P2: adult oil palm area near Lau river (planted in 1992), P3: housing complex at oil palm plantation, P4: adult oil palm area at Marihat, Block A (planted in 1989), P5: housing 1 at the sub-district town, P6: housing 2 at the sub-district town, P7: cocoa area, P8: village housing, PR: at the side of Lau River.

Table 8 shows that the highest concentration of calcium $(\mathrm{Ca})$ in the water samples was obtained at $\mathrm{P} 7$ water sampling 60 days after fertilization, which was $81.16 \mathrm{mg} \mathrm{L}-1$. The lowest calcium (Ca) concentration value of the water samples was obtained from P3 water sampling 0 days after fertilization, which was $0.48 \mathrm{mg} \mathrm{L}-1$. This means that the fertilizer treatment did not fully affect the concentrations of calcium $(\mathrm{Ca})$ in groundwater. The high concentration of Calcium in the water samples may be due to the dissolution of limestone caused by dolomite fertilizer application. Alamendah (2010) stated that these domestic wastes are in the forms of organic and inorganic wastes such as detergents. In accordance with the standard set by WHO (1993), the inter-regional water study-group is between 75 and $150 \mathrm{mg} \mathrm{L}-1$.

Based on the LSD test on Day 90 after fertilization, it was revealed that P4 was significantly different for all the treatments. This means the fertilizer treatment did not fully affect the concentrations of calcium $(\mathrm{Ca})$ at ground water in the surrounding area.

3.8 Magnesium (Mg) Analysis

Magnesium $(\mathrm{Mg})$ analysis of the water samples in this study is presented in Table 9 below:

Table 9. Analysis of Magnesium (Mg) in the Water Samples

\begin{tabular}{|c|c|c|c|c|c|c|c|c|c|c|c|c|c|c|c|}
\hline \multirow[t]{2}{*}{ Parameter } & \multirow{2}{*}{$\begin{array}{l}\text { Sample } \\
\text { P1 }\end{array}$} & \multicolumn{2}{|c|}{ Day 0} & \multicolumn{2}{|c|}{ Day 3} & \multicolumn{2}{|c|}{ Day 7} & \multicolumn{2}{|c|}{ Day 14} & \multicolumn{2}{|c|}{ Day 30} & \multicolumn{2}{|c|}{ Day 60} & \multicolumn{2}{|c|}{ Day 90} \\
\hline & & 0.03 & $\mathrm{~F}$ & 0.21 & $\mathrm{CD}$ & 0.37 & $\mathrm{C}$ & 0.33 & $\mathrm{C}$ & 0.32 & $\mathrm{E}$ & 0.31 & $\mathrm{C}$ & 0.35 & $\mathrm{~F}$ \\
\hline \multirow{9}{*}{$\begin{array}{l}\text { Magnesium } \\
\text { mg L L }^{-1}\end{array}$} & $\mathrm{P} 2$ & 0.15 & $\mathrm{E}$ & 0.53 & $\mathrm{AB}$ & 0.31 & $\mathrm{C}$ & 0.28 & $\mathrm{C}$ & 0.28 & $\mathrm{E}$ & 0.26 & $\mathrm{C}$ & 0.24 & $\mathrm{~F}$ \\
\hline & P3 & 0.05 & F & 0.13 & $\mathrm{CD}$ & 0.22 & $\mathrm{C}$ & 0.22 & $\mathrm{C}$ & 0.28 & $\mathrm{E}$ & 0.23 & $\mathrm{C}$ & 0.19 & $\mathrm{~F}$ \\
\hline & $\mathrm{P} 4$ & 0.86 & A & 0.67 & A & 1.50 & A & 1.51 & A & 3.40 & A & 3.40 & A & 3.35 & A \\
\hline & P5 & 0.36 & $\mathrm{D}$ & 0.25 & $\mathrm{C}$ & 1.26 & A & 1.14 & B & 1.35 & $\mathrm{C}$ & 1.55 & B & 1.26 & $\mathrm{D}$ \\
\hline & P6 & 0.80 & $\mathrm{AB}$ & 0.66 & A & 1.51 & A & 1.50 & A & 3.28 & $\mathrm{AB}$ & 3.31 & A & 3.21 & A \\
\hline & P7 & 0.73 & $\mathrm{~B}$ & 0.62 & A & 1.47 & A & 1.49 & A & 3.18 & $\mathrm{AB}$ & 3.26 & A & 2.93 & B \\
\hline & P8 & 0.51 & $\mathrm{C}$ & 0.45 & B & 0.81 & B & 0.91 & B & 0.98 & $\mathrm{D}$ & 1.05 & B & 0.65 & E \\
\hline & PS & 0.07 & $\mathrm{EF}$ & 0.07 & $\mathrm{CD}$ & 0.41 & $\mathrm{C}$ & 0.29 & $\mathrm{C}$ & 0.34 & $\mathrm{E}$ & 0.31 & $\mathrm{C}$ & 0.27 & $\mathrm{~F}$ \\
\hline & Run-Off & 0.15 & $\mathrm{E}$ & 0.27 & $\mathrm{C}$ & 1.52 & A & 1.53 & A & 2.97 & B & 3.49 & A & 2.61 & $\mathrm{C}$ \\
\hline
\end{tabular}


*Note. The values followed by the same letters in the same column are not significantly different at $\mathrm{P} \geq$ 5\% (LSD), P1: young oil palm area, P2: adult oil palm area near Lau river (planted in 1992), P3: housing complex at oil palm plantation, P4: adult oil palm area at Marihat, Block A (planted in 1989), P5: housing 1 at the sub-district town, P6: housing 2 at the sub-district town, P7: cocoa area, P8: village housing, PR: at the side of Lau River.

Table 9 shows that the highest concentration of magnesium $(\mathrm{Mg})$ in the water samples was obtained from the runoff water sampling 60 days after fertilization, which was $3.49 \mathrm{mg} \mathrm{L}-1$. The lowest magnesium $(\mathrm{Mg})$ concentration value was obtained from P1 water sampling on Day 0 before fertilization, which was $0.03 \mathrm{mg} \mathrm{L}-1$. Magnesium (Mg) solubility in water was $12 \mathrm{mg} \mathrm{L}-1$, thus, it can be concluded that the content of magnesium $(\mathrm{Mg})$ in the water samples at the plantation experimental area did not cross the threshold of drinking water standard.

According to Bahtiar (2007), there are no known cases of magnesium $(\mathrm{Mg})$ poisoning. Large oral doses of magnesium $(\mathrm{Mg})$ may cause vomitting and diarrhea. Furthermore, high doses of magnesium in medicine and food supplements may cause muscle slackening, nerve problems, depression, and personality changes. In animals such as in cattle, high doses of magnesium $(\mathrm{Mg})$ can cause scouring and diarrhea. Nevertheless, magnesium (Mg) levels up to $2000 \mathrm{mg} \mathrm{L}-1$ have been observed to have no adverse effects. There is insufficent information available at present to set a guideline value.

Based on the LSD test on day 90 after fertilization, the results revealed that P4 was not significantly different from P6, but it was significantly different from the other treatments. This means that the fertilizer treatment did not fully affect the concentrations of magnesium $(\mathrm{Mg})$ in groundwater.

\section{Conclusion}

The $\mathrm{pH}$ of water samples and concentrations of Nitrate-N (NO3-), Nitrite-N (NO2-), Ammonium-N (NH4), Phosphate (P), Potassium (K), Calcium (Ca), and Magnesium (Mg) at oil palm plantation did not exceed the contamination levels for safe drinking water as set by WHO. In general, $\mathrm{pH}$, Nitrate-N (NO3-), Nitrite-N (NO2-), Ammonium-N (NH4), Phosphate (P), Potassium (K), Calcium (Ca), and Magnesium $(\mathrm{Mg})$ concentrations increased after fertilizer application but eventually decreased with time.

This study has shown that fertilizer treatments in the oil palm plantation did not reduce the quality of groundwater. However, it was found that Ammonium-N (NH4) value was high in the housing complex, exceeding the safe drinking water standard set by WHO.

\section{Refferences}

Alaerts, G., \& Santika, S. S. (1987). Water Research Methods. Publisher National Business Surabaya. Alamendah. (2010). Causes and Effects of Air Pollution by Waste Settlement. Retrieved from http://alamendah.wordpress.com/2010/09/27/ 
APHA, AWWA-WEF. (1992). Standard Methods for Examination of Water and Wastewater (20th ed.). American Public Health Association, Washington DC.

Bahtiar, A. (2007). Groundwater Pollution Due to Industrial and Household Waste as Well as the Solution. Paper Faculty of Mathematics and Natural Science, Padjadjaran University of Indonesia.

Buckmand, H. O., \& Brady, N. C. (1982). Soil Science. Soegiman Translation (p. 788). Brata script works. Jakarta.

Divya, J. (2012). Impact of chemical fertilizers on water quality in selected agricultural areas of Mysore district (Vol. 2, No. 3). Kaaarrrnataka, India,

Effendi, H. (2003). Assessing Water Quality for Management of Water Resources and Environment (p. 249). Kanisius, Yogyakarta.

Galloway, J. N. (1995). Acid deposition: Perspectives in time and space. Water, Air, Soil Pollution, 85, 15-24. https://doi.org/10.1007/BF00483685

Hammer, \& Viessman. (2005). Water Supply and Pollutan Control (p. 867). Pearson Prentice Hall: Technology \& Engineering.

Harahap, I. Y. (2009). Depth of Soil Water Dynamics Advances in Oil Palm Plantation and Surrounding Areas. Journal of Oil Palm Research Centre Medan.

Jeyaruba, T., \& Thushyanthy, M. (2009). The Effect of Agriculture on Quality of Groundwater: A Case Study. Departement of Agric. Engineering Faculty of Agriculture, 4(2), 110-114.

Kristianto, P. (2002). Industrial Ecology. ANDI Publisher. Yogyakarta.

Kumar, D. (1987). Environmental Chemistry. Willey Eastern Limited. New Delhi.

Michinori, N. (2002). Effect of Intensive Fertilizer Use on Groundwater Quality. Institute of Agricultural and Forest Enginerering. Japan: University of Tsukuba.

Ogunwale, J. A., \& Azzez, K. O. (2000). Characterization, classification and potassium speciation of soils at Igbeti Nigeria. African Scientists, 1, 83-94.

Petronella, G., Ah Tung, Mohd, K. Y., Nik, M. Majid., Goh Kah, J., \& Gan, H. (2009). Effect of N and K Fertilizer on Nutrient Leaching and Groundwater Quality under Mature Oil Palm in during the Monsoon Period. American journal of Applied Sciences, 6(10), 1788-1799. https://doi.org/10.3844/ajassp.2009.1788.1799

PPKS. (1999). Eligibility Study of Oil Palm Plantation Development KKPA KUD BumiAsih. Kec. Tandun, Kab. Kampar, Riau with the Adopted Father of PT. Perkebunan Nusantara V Ex. 99161,Indonesia.

Sastrawijaya, T. (2000). Environmental Pollution. Rineka Notices. Bandung.

Utama, W. H. (2008). Nitrate and Nitrite Poisoning. http://www.food4healthy.wordpress.com/2008/08/27/keracunan-nitrit-dan-nitrat/

Van Der Hoek, K. W. (1994). Method for Calculation of Ammonia Emission in the Netherlands for the Year 1990, 1991 and 1992 (in Dutch). RIVM Report 773004003. RIVM, Bilthoven, the Netherland. 
Van Es, H. M., Czymmek, K. J., \& Kettetings, Q. M. (2002). Management effect on nitrogen leaching and guidelines for a nitrogen leaching index in New York. J. Soil Water Conservation, 57, 499-504. Retrieved from http://www.jswconline.org/content57/6/499.abstract

WHO. (1993). Guidelines for Drinking Water Quality (2nd ed., p. 118). Geneva, World Health Organization, ISBN: 9241544600.

Widodo, P. (2008). Potential Groundwater Contamination by Nitrogen Fertilizer Application on Melon Crops in the District of Klaten Regency Kebonarum. Research for Thesis S-1. Faculty of Geography, University of Muhammadiyah Surakarta, Indonesia.

Winata, I. N. A. et al. (2000). Comparison of total content of P and N in Water River Plantation and Rice fields in the environment. BASIC SCIENCE Journal. 